\title{
Contributions to the macromycetes in the oak zone of Finland
}

\author{
Paavo Kallio and Esteri Kankainen \\ Department of Botany, University of Turku
}

Publications from the Department of Botany, University of Turku, N:o 114

The characteristics of the fungus flora of the oak zone of Finland have to some extent been described in the papers of Karsten (1859), Thesleff (1919), EkLund $(1943,1944)$, and Kallio (1963). The northern limit of the oak zone is one of the clearest mycofloristic boundaries in northern Europe and some species - e.g. many boletes (Kaltio 1963) - are particularly good indicators for this zone.

In the following list, new localities of some ssouthern species» are attached as addenda to the list of Kallio (1963). Some new points for study have been included in the collecting operations and some of the localities mentioned in the previous list have been collected again.

The nomenclature follows that of Singer (1962; Agaricales) and Moser (1963; Ascomycetes). All the specimens mentioned are preserved in TUR (Herbarium of the University of Turku).Abbreviations of persons: (SH) Seppo Hietavuo, (EK) Esteri Kankainen, (PK) Paavo Kallio, (AN) Antti Nyman, (RS) Raili Suominen. Abbreviations of provinces: $A=$ Ahvenanmaa, $V=$ VarsinaisSuomi, $\mathrm{U}=$ Uusimaa, $\mathrm{St}=$ Satakunta, $\mathrm{EH}$ $=$ Etelä-Häme, EK = Etelä-Karjala.

\section{LIST OF THE SPECIES}

\section{Ascomycetes}

Xylaria hypoxylon (L.) Dumortier

A: J o ma la Ramsholm 20.9.64 (PK). V: T u r $\mathrm{ku}$ Ruissalo 4.10.56 (PK) and 27.9.64 (Aarne Vuorisalo); P i ik k i ö Tuorla 20.9.60 (PK); N a u vo Vikom (on Betula) 10.11.57 (PK), Storträsk (on Betula) 10.11.57 (PK); K e m i ö Viik 18.9.65 (EK). U: In k o o Fagervik (on Quercus) 4.11.65 (Holger Såltin). - The species has also been collected in localities north of the oak zone.

Xylaria polymorpha (Pers.) Dumortier

U: In k o o Fagervik (on Quercus trunk) 4.11. 65 (Holger Såltin).

Bulgaria inquinans Fr.

V: T u rk u Ruissalo, Sept. 1922 (L. E. Kari), 13. 9.36 (L. E. Kari). 10.9.60 (PK), 16.9.65 (PK, Paula Siltanen); K e m i ö Viik 18.9.65 (EK, PK, Heli Heikkilä), 10.9.66 (PK \& Paula Siltanen); $\mathrm{M}$ ie toinen Saari 17.9.65 (PK); Halikko
Vuorentaka23. 10. 66 (AN); Karja loh ja Piipola Heponiemi 12.9.65 and 25.9.66 (AN). The fungus grows on Quercus. Helvella crispa (Scop.) Fr.

V: Halikko Vaisakko, on leaves of oak and poplar 2.10.65 (AN); P a ra i n en Urheilukenttä 7. 10.65 (RS).

\section{B a sidiom ycetes \\ Polyporaceae}

Laetiporus sulphureus (Bull.) Bond. \& Sing.

V: Ra is io Viheriäinen 1964 (Tapio Laine, private communic.), Ke mi ö Viik 18.9.65 (PK), 10.9.66 (PK). The species is found always on Quercus.

Polypilus frondosus (Dicks.) Karst.

V: T u rk u Ruissalo 26.9.65 (Paula Siltanen), K e m i ö Viik 4. 10.64 (EK, AN etc.), 10.9.66 (PK), 
$\mathrm{R}$ a i s i o Perno Tammimäki 25.9.66 (Tapio Laine). The fungus grows at the base of old oaks.

Polypilus umbellatus (Pers.) Bond. \& Sing.

V: Pa rainen Attu 30.8.65, 27.9.67 (SH). This is the second known discovery of the species in Finland (cf. Kallio 1963).

Daedalea quercina (L.) Fr.

V: Ke mï̈ Viik 18.9.65 (PK); U u sika u p unki Saraperä 21.9.65 (P'K); Ve h ma a Vinkkilä Saarikko 21.9.65 (PK). The species is common on oak stubs.

Fistulina hepatica (Schaeff.) Fr.

V: H a likk o Tavola, on living Quercus 19.9. 66 (AN); Karja lo h ja Piipola Heponiemi, on living Quercus 25.9.66 (AN). The species has been found every year in the surroundings of Turku.

\section{Tricholomataceae}

Laccaria amethystina (Bolt. ex Hooker) Murr. V: Turku Ruissalo 16.9.65 (EK); K e mï̈ Viik 18.9.65 (PK); Uskela Tupuri 10.10.66 (AN).

\section{Tricholoma lascivum (Fr.) Gillet}

V: Kemiö Viik, under oaks 10.9.66 (PK).

Tricholoma sulphureum (Bull. ex Fr.) Kummer

V: Turku Hirvensalo 3.10.65 (Kalevi Viljamaa); Ke m i ö Viik 18.9.65 (EK \& PK), 10.9.66 (PK); P a i m i o Askala (under hazel) 26.9.65 (Reino Alava); $\mathrm{R}$ a is io Perno 28.9.66 (EK); M i e t o in en Saari 17.9.65. (PK); V e h m a a Vinkkilä Saarikko, oak-hazel forest 21.9.65 (PK); U u s i k a u punki Sundholma 21.9.65 (PK); Laitila Varpe, pure Corylus locality (without oak) 21.9.65 $(\mathrm{PK})$, church village (under oak) 21.9.65 (PK), and Mustasalo, oak-hazel forest 21.9.65 (PK); P a r a i n e n Lenholm under oak 19.9.66 (SH).

Tricholoma columbetta (Fr.) Kummer

V: Ke miö Viik 18.9.65 (PK), 10.9.66 (PK); Angelniemi Kokkila 4.10.64 (RS), 10.9 .66 (EK); Pohja Skuru 30.10.65 (Holger Såltin); Laitila Varpe 21.9.65 (PK). St: Eurajoki Kaunissaari 29.9.63 (Matti Sulkinoja); P a r a in e $\mathrm{n}$ Lenholm, near oak 19.9.66 (SH).

Oudemansiella radicata (Relh. ex Fr.) Sing.

V: Turku Katariinanlaakso 23.9.63 (PK), 18.

11. 63 (EK), and Ruissalo 24.9.63 (PK).

Marasmiellus ramealis (Bull. ex Fr.) Sing.

V: Turku Ruissalo 9.9.66 (EK); K e m i ö Viik 10.9.66 (PK); P o h j a Fiskars 26. 10.65 (Holger Såltin); H a lik k o Vuorentaka 18.9.65 (AN); Nousia in en Linnavuori 17.9.65. (Heli Heikkilä); V e hm a a Vinkkilä Saarikko 21.9.65 (PK); Uusika u unki Sundholma 21.9.65 (PK) Laitila Varpe 21.9.65 (PK), and Mustasalo 21. 9.65 (PK). U: I n k o Fagervik 4.11.65 (Holger Såltin).

Marasmius prasiosmus (Fr.) Fr.

V: K e m i ö Viik, oak forest 4. 10.64 (EK); U s kela Tupuri 10.10.66 (AN); $\mathrm{Halikk} \mathrm{o}$ Vaisakko 23. 10.66 (AN); Ka r ja lo h ja Piipola Heponiemi 25.9.66 (AN). The last find seems to be the only find during September (cf. Kawro 1963, p. 48). The species grows on decaying oak leaves Mycena inclinata (Fr.) Quél.

V: Turku Ruissalo 25.9.64 (EK); K e m i ö Viik 4.10.64 (EK), 18.9.65 (EK), 10.9.66 (EK). Abundant on old oak stubs.

\section{Amanitaceae}

Amanita pantherina (D. C. ex Fr.) Schumm.

V: Ha likko Märy Pihko, under oaks 10.9.66 (AN); P a rain en Attu 22.8.66 (SH).

Amanita phalloides (Vaill. ex Fr.) Secr.

The distribution of this rare species in Finland is only a little known. The following specimens labelled with the name "phalloides» are preserved: Amanita phalloides Fr. forma alba Särkijärvi (Tammela) 24. Sept. 1867. - Agaricus phalloides Mustiala 1876 (or 1870). - Amanita mappa Batsch var. phalloides Runsala (=Turku, Ruissalo) 4. Sept. 1881. All these specimens have been collected by P. A. Karsten. Thesleff has found one specimen in south Karelia, Björkö 17. IX. 1894. W. Nyberg has labelled »Amanita phalloides Fr. - Nästan vit färgform. Grankulla, Sept. 1941, i blandskog, osäker».

The specimens collected by Karsten are very small. The cap is only $3 \mathrm{~cm}$ broad and the stipe 2-4 $\mathrm{mm}$ thick. The appearence is quite different from those collected by us from $T u r k u$ Ruissalo. The appearance of the specimens of Karsten resembles most closely Amanita porphyria (Alb. \& Schw.) Fr. It is probable that Karsten in his labels has meant Amanita phalloides Secr., which is the same as $A$. porphyria (cf. VeselÝ 1934, p. 17). KarsTEN (1876, pp. 23-24) records Agaricus porphyrius and as its synonym $\gg$ Agaricus phalloides e.Fr. Syst. Myc. I. P. 13*, and has added in his description: "formam majorem huius speciei ( $\mathrm{Ag}$. sinuatum Schum.) stipite bulboso farcto ad $\mathrm{Ag}$. phalloidem, quocum statura omnino conventit, olim retulimus». In $1879^{\prime}$ (p. 2) Karsten used the name Amanita bulbosa (Schaeff.) Pers. and recorded its distributional area "Ryssl. (Ural.); Scand.» indicating that the species had not been found in Finland previously.

Also the specimen collected by Thesleff cannot further be determined. The specimens collected by Nyberg have quite another type of the stipe base than this phalloides we know, and we want to underline the designation »osäker» (=not sure). Eklund has mentioned that the species occurs in the archipelago of Turku (1943; p. 18). In both localities, in Korppoo like in Houtskari, the habitat has been a meadow forest also growing oak. No collections are preserved from these localities. STENur has (1947) recorded the species from Ahvenanmaa Lemland: Nâtö.

In 1963 Amanita phalloides was found in V: Kakskerta Kulho (20.9.) by Ulla Laaksonen. The habitat is a rich oak forest known by its southern fungi (cf. Kaluro 1963). In the same year the species was found by the authors in two localities in $\mathrm{Tu} \mathrm{rku}$ Ruissalo. 1. Oct. in all ten fruit bodies were found. The fruit bodies are most typical when compared with the description by LANGE 1935. The largest caps were $14 \mathrm{~cm}$ in diameter and the stem was in all specimens more than one $\mathrm{cm}$ thick. The tallest specimens were $16 \mathrm{~cm}$ in height. The colour of the fruit bodies was typical olive greenish, and some of the colour was seen in the stem. On some caps remnants of the volva were seen. These were gray or grayish white. The volva was wide and somewhat greenish in colour. - The habitat was a luxuriant meadow forest west of the conservation area of Ruissalo. Tilia is the dominant tree. Later the species was found also in a forest west of the *conservation area». It was found also in 1965 and 


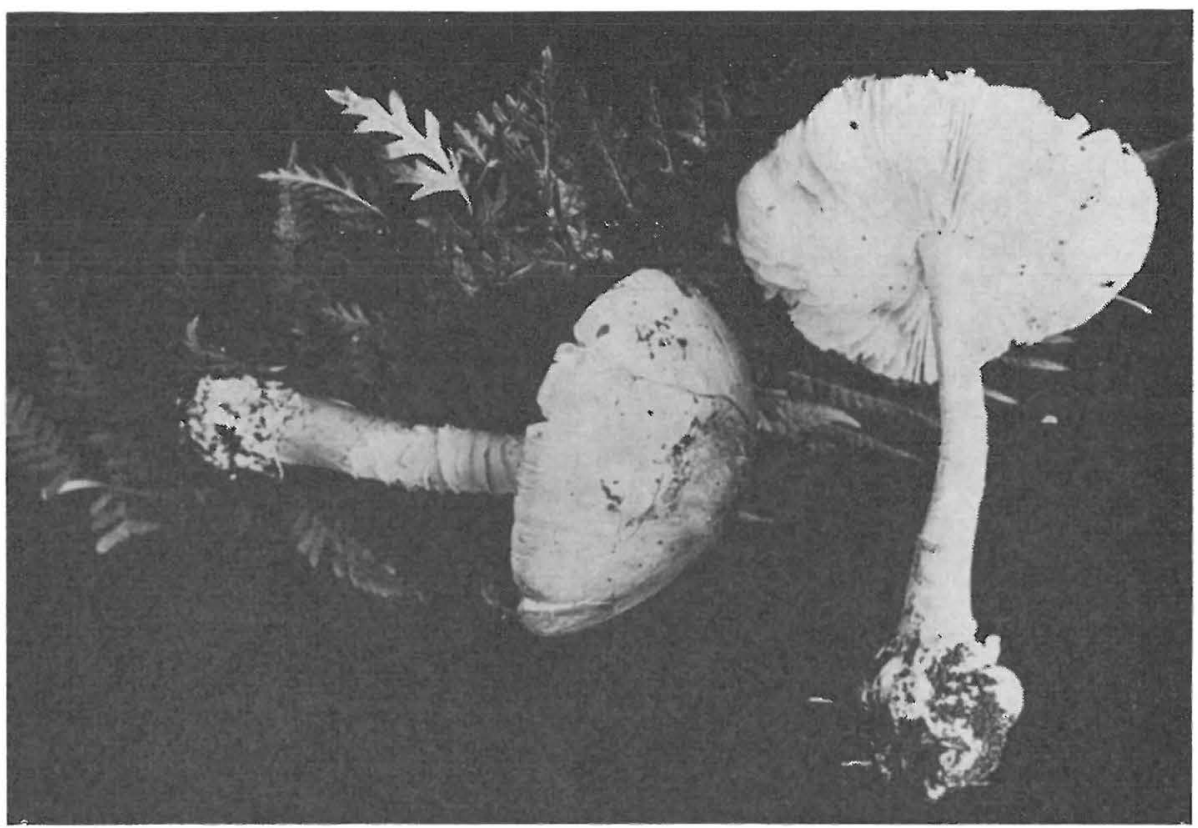

Fig. 1. Amanita phalloides from Ruissalo.

in 1966 (one not well developed fruit body). In 1967 A. phalloides was found by Antti Nyman in $\mathrm{Ha}$. lik ko. It is probable that the distribution of this species is restricted to the oak zone in Finland.

Amanita junquillea Quél.

This species has earlier been recorded from Finland by KaLito (1952) but no specimen is preserved It was found 3.9.1965 in V: Raisio Kallastenmäki by Ulla Laaksonen (LAaKsonen 1966). To this species belongs also in all probability a specimen in $\mathrm{H}$ with a label: Amanita mappa (Willd.). Ab, Pojo Brödtorp, Björkkulla, leg. E. Hisinger. Fyndet Gjort någon Gâng kring år 1860».

The Raisio specimen corresponds in all details with the description of PrLÁt 1932 and Lange 1935. Fig. 117 below to the left in PrLÁt 1954 is exactly similar to our specimen.

The habitat of the Raisio locality is pine growing rocky heath on a hill slope above a hazel copse with some old oaks. The associates were Pleurozium schreberi (60\%), Luzula pilosa, Calamagrostis arundinacea, Maianthemum bifolium. The acidity of the soil was pH 4.4.

The species is rare both in Denmark and southern Sweden, where it has first been found in 1936 (Lundell \& NANNFELDT 1936). In Finland it is obviously a southern termophilous species (cf. PILÁt 1954, p. 117).

Amanita citrina (Schaeff.) S. F. Gray

A: Le m land Flaka 11.9.63 (EK). V: Ke $\mathrm{miö} \mathrm{Viik} \mathrm{18.9.65} \mathrm{and} \mathrm{10.9.66} \mathrm{(PK);} \mathrm{P} \mathrm{a} \mathrm{ra} \mathrm{i} \mathrm{-}$ nen Peksor 17.9.66 (SH); Uusikaupunki Sundholma 21.9.65 (PK); V e h m a a Saarikko 21. 9. 65 (PK); Laitila Varpe 21.9.65 and Mustasalo 21.9.65 (PK). EK: K y m i Saksala 18.9.66 (Kalevi Viljamaa).

Amanita spissa (Fr.) Kummer.

$\mathrm{V}$ : Turku Ruissalo, roadside near Kansanpuis- to, under Tilia (in the square no. 101 by LINDGREN 1954) 29.4.64 (EK \& PK), 1. 10.64 (PK), 24.8.65 (Ulla Laaksonen), 4.9.65 (EK \& PK). The species was abundant in 1964 and 1965, but in 1966 it was not found. The habitat is dry and almost barren ground.

\section{Boletaceae}

Gyroporus cyanescens (Bull.) Quél.

V: K e m i ö Viik, oak forest 18.9.65 (EK); K is k o Niemenkylä 12.9.65 (Hanna Heiskanen). EK: Virolahti Eerikkilä, sandy pine forest 23.9.65 (Tapio Rintanen), and Ravijoki Lapuri, on sand 12.9.65 (Tapio Rintanen). - In these specimens two different types of habitats are represented: a luxuriant meadow forest and sandy open soil.

Gyroporus castaneus (Bull. ex Fr.) Quél.

V: T urku Ruissalo, west of the nature protection area, on barren ground (roadside) under oaks 24.8.66 (SH), 9.9.66 (PK).

Suillus granulatus (L. ex Fr.) O. Kuntze

A: J o ma la roadside between Jomala and Lemland 20.9.64 (PK). V: T u rk u Katariinanlaakso 23. 9.63 (PK); K o r p p o o Ãvensor Karheri 25.9. 66 (PK). The species was found in many places in $\mathrm{P}$ a $\mathrm{r}$ a in en, where it seems to be rather common in pine forests on calcareous soil. The $\mathrm{pH}$ value of some habitats has been measured and it is mostly about 7 (6.4-7.6). The specimens from Parainen (SH): Peksor, $\mathrm{cp}$ in pine forest 28. 7.65; Kurchas 30 . 7.65; Ersby-Simonkylä 28.7.65; Mustfinnö 3.9.66. Xerocomus chrysenteron (Bull. ex St.Am.) Quél. A: J o mala Ramsholm 20.9.64 (PK). V: K e $\mathrm{m}$ i ö Viik 18.9.65 (PK); K o r p p o o Åvensor 
Karheri 25.9.66 (PK); $\mathrm{P}$ a ra in e n Peksor 10.8. 65 and 16.8.66 (SH), Lenholm 10.8.65, Attu 16.8. 65 . Always near oak or hazel.

Boletus edulis Bull. ex Fr. var. reticulatus (Schaeff.) Boud.

V: Halikko Märy Pihko, under oaks 22. 8. 66 (AN); P a rain e n Lenholm, near oaks 30.8 . $66(\mathrm{SH})$

Boletus erythropus (Fr. ex Fr.) Pers.

V: Kakskerta Järvistensaari 15.7.66 (Pirjo Karunen); Parainen Peksor 31.8. and 7.7.65 (SH). Lenholm 30.8.66 (SH). EH: T a m pere Kaupinmetsä 15.9.65 (Maija Rantala). This very typical specimen of the species is thus found north of the oak zone and there were no oaks or other southern "trees in the vicinity, but only pine and birch.

Boletus luridus Schaeff. ex Fr.

A: E ckerö Skag 12.9.63 (EK); Le m land Flaka 11.9.63 (EK). The species grew in mixed forest with oaks.

\section{Russulaceae}

Russula laurocerasi Melz.

V: T u rku Ruissalo, at the spring of Choraeus and at the roadside to Pikkupukki 10.9.56 (PK), Ruissalo 24.8.65 (RS), Katariinanlaakso 17.9.63 (RS); R a isio Perno 21.9.63 (RS); $\mathrm{H}$ a $1 \mathrm{ikko}$ Tavola 18.9.65 (AN). All the habitats are near oaks. The species is easily discerned from $R$. foetens by the odour and the form of the spores.

Russula lepida Fr.

The species, which has not been closely described from Finland (cf., however, Rautavaara 1947: I p.), is like the more common $R$. pseudointegra Arn. \& Goris. The spore colour is, however, white and the stem has often the same reddish colour as the cap. All characteristics agree with the description by SCHAEFFER (1952).

V: Turku Ruissalo, Kauppila 2. 10.63 (RS); $\mathrm{H}$ a l ik ko Pihko 2. 10.63 (RS). Both localities are rather luxuriant meadow forests with Picea, Corylus and Quercus. According to ScHAEFFER (1952) $R$. lepida is a typical fungus in the beech forests of south and central Germany.

Russula lutea (Huds. ex Fr.) Fr.

V: Turku Ruissalo 7. 10.63 (RS), Katariinanlaakso 26.9.56 (PK), 4.9.61 (PK), 28.9.63 (RS); $\mathrm{K}$ a arina Karpanmäki, Sept. -60 (PK); Kakskerta Kulho Linnavuori 29. 8. 62 (PK); L i e to Vieru 11. 9. 66 (Paula Siltanen); Ha likko Vaisakko 16.9. 62, 15.9.63 (RS), Pihko 15.9.63 (RS), Tavola 18.9. 65 (AN); U s k e l a Veitakkala 15.9.63 (RS); K e miö Viik 10.9.66 (EK). EH: Asikkala Vääksy 17.8.62 (Lahja Hakala). Although the species is not restricted to the oak zone in Finland, it is, however, a typical fungus in Ruissalo and in other oak forests in Turku area.

Russula aurata (With.) Fr.

A: Jomal a Gottby 21.9.64 (PK and RS). V: Turku Ruissalo, rich copse with Quercus, Tilia etc. 15.9.67 (RS); $\mathrm{Ha} \mathrm{lik} \mathrm{ko} \mathrm{Vaisakko} \mathrm{15.9.63}$ (RS), 26. 8.65 (RS). The habitat in A was a dry pine forest on rock ground (with Cladina-lichens). In $\mathrm{Ha}$ likko the habitat was a rather rich meadow forest with $\mathrm{pH} 5.9$ and with the typical vascular plants: Picea, Corylus, Rhamnus frangula, Quercus.
Russula olivacea (Schaeff. ex Schw.) Fr.

This species resembles somewhat the more common $R$. cyanoxantha, from which it is, however, easily separated by the coloured spore powder. All the characteristics agree with those of the fruit bodies collected by the author, Kankainen, in Denmark.

V: T u rk u Ruissalo, oak forest near the spring of Choraeus 24.9.63 (PK). The species is not recorded from Finland previously. In south and central Germany it is one of the most common species (Schaefrer 1952).

Russula pseudointegra Arn. \& Goris

V: Turku Ruissalo 28.9.63 (RS), 7.10.63 (RS), 24.8.65 (RS), 2.9.65 (PK), 8.10.65 (RS); $\mathrm{R}$ a i si o Perno 17.9.65 (Ulla Laaksonen), Vatsela Kallastenvuori 6.9.65 (EK); K e m i ö Viik 18.9. 65 (EK), 10.9.66 (PK). Very common in Ruissalo in 1966 .

Lactarius volemus (Fr) Fr.

V: Turku Ruissalo 4.9.65 (PK) and 9.9.66 (PK); P a rainen Pettiby 20.8.66 (SH); K e mi ö Viik 10.9.66 (PK); Ha likk o Tavola 18. 9.65. (AN); P i i k k i ö Pukkila 25.9.66 (Saara Tamminen); $R$ a isio Kallastenvuori 6.9.65 (PK \& EK); N a a n tali Luonnonmaa 17.9.66 (Paula Siltanen); M i e t o i n e n Saari 17.9.65 (PK). EK: Virolahti Ylä-Säkäjärvi 7.9.66 (Tapio Rintanen).

Lactarius azonites Bull. ex Gmel.

V: Ke m i ö Viik 18.9.65 (EK \& PK), and 10.9. 66 (EK \& PK); $\mathrm{R}$ a is i o Perno 17.9. 65 (EK). The species was found in oak forest.

Lactarius piperatus (L. ex Fr.) S.F. Gray

A: Le m l a nd Flaka Herrö 11.9.63 (EK). V: T u rk u Katariinanlaakso 2.9.65 (PK); K e m i ö Viik 4.10.64 (RS) and 18.9.65 (EK); $\mathrm{Halikk} \mathrm{o}$ Vaisakko 10. 10.65.

Lactarius glaucescens Crossl.

V: Ke m i ö Viik 18.9.65 (PK); Ka r ja lo h ja Piipola Heponiemi, oak forest 12.9.65 (AN); $\mathrm{H}$ a lik k o Keravuori in a rich hazel copse 1965. (AN, private communic.); $\mathrm{M}$ i e to in en Saari, oak forest 17.9.65 (PK).

Lactarius vellereus (Fr.) Fr.

V: Ke miö Viik 4.10.64 (EK), 10.9.66 (PK); $\mathrm{M}$ ietoinen Saari 17.9.65 (PK); Uusikaupunki Sundholma 21.9.65 (PK). EK: ViroI a h t i Ravijoki-Länsikylä, birch forest 15.9 .65 (Tapio Rintanen).

Lactarius quietus Fr.

V: Ke mï̈ Viik 4.10.64 (EK), 18.9.65 (EK \& PK) and 10.9.66 (PK); $\mathrm{Halikko}$ Vaisakko and Pihko 10. 10.65 (AN); K a r ja 1 o h ja Piipola Heponiemi 12.9.65 (AN); $R$ a i s i o Kallastenvuori 6. 9.65 (EK \& PK).

\section{Cantharellaceae}

Craterellus sinuosus (Fr.) Fr.

V: Ke miö Viik 18.9.65 (EK \& PK), and 10.9. 66 (EK \& Paula Siltanen). The species grows in oakhazel forest.

$$
\text { Gasteromycetes }
$$

Lycoperdon echinatum Pers.

V: Halikko Vuorentaka Vaisakko 2.10.65 (AN). About twenty specimens were growing under oak. 


\section{REFERENCES}

EkLund, O., 1943: Zur Pilzflora des Schärenarchipels SW-Finnlands. Mem. Soc. F. Fl. Fenn. 18, $2-20$.

- 1944: Weitere Beiträge zur Pilzflora des Schärenarchipels SW-Finnlands. - Ibid. 19, 212-216.

KALlIO, P., 1952: Kärpässienihavaintoja Turun tienoilta. - Luonnon Tutkija 56, 29.

- 1963: Zur Verbreitung einiger in Finnland südlichen Pilze, besonders in der südwestlichen Eichenzone. - Karstenia VI-VII, 35 -76 .

Karsten, P. A., 1859: Sydvestra Finlands Polyporeer. - Akad. afhandl. 47 pp. Helsinki.

- 1876: Mycologia Fennica III. Basidiomycetes. - Bidr. Känned. Finl. Natur och Folk 25, 1377.

- 1879: Rysslands, Finlands och den Skandinaviska Halföns hattsvampar I. - Ibid. 32, 1571.

- 1882: Rysslands, Finlands och den Skandinaviska Halföns hattsvampar II. - Ibid. 37, 1257.

LAAKsonen, U., 1966: Suomen Amanita junquillealöydöistä. - Luonnon Tutkija 70, 163-165.

LINDGREN, L., 1954: Ruissalon putkilokasvisto. Turun Ylioppilas 3, 145-181.
Lundell, S. \& J. A. Nannfeldt, 1936: Svenska svampar, särskilt från Upsala-trakten. Fungi exsiccati Suecici, praesertim Upsalienses VII -VIII. Uppsala.

Moser, M., 1963: Ascomyceten. - In H. Gams: Kleine Kryptogamenflora II a, 1-147.

Nrman, A., 1967: Mycofloristic findings from $\mathrm{Ha}$ likko, SW Finland. - Karstenia VIII, 21-24.

PiLÁt, A., 1954: Pilze, mit 120 farbigen Tafeln nach Aquarellen von Otto Ušák. - 344 pp. Ams terdam.

RautavaAra, T., 1947: Suomen sienisato. - 534 pp. Porvoo-Helsinki.

Schatfrer, J., 1952: Russula-Monographie. Die Pilze Mitteleuropas III. - 296 pp. Bad Heilbrunn.

Singer, R., 1962: The Agaricales in modern taxonomy. - 915 pp. Weinheim.

StenLID, G., 1947: Några anteckningar om Ålands svampflora. - Mem. Soc. F. Fl. Fenn. 23, $82-90$.

TheslefF, A., 1919: Studier öfver basidsvampfloran i sydöstra Finland med hänsyn till dess sam. mansättning, fysiognomi, fenologi och ekologi. - Bidr. Känned. Finl. Natur och Folk 79:1, $1-140$.

Veselý, R., 1934: Amanita. - In Kavina, C. \& A. Pilát: Atlas des Champignons de l'Europe. 80 pp. Praha. 